\title{
MENINGKATKAN PRESTASI BELAJAR SISWA SMA PADA MATERI GELOMBANG BUNYI MENGGUNAKAN STRATEGI MULTIPLE INTELLIGENCES
}

\author{
VANTRI PIETER KELELUFNA ${ }^{1}$ AGUSTINUS LIA MASAN $^{2}$ \\ Fakultas Keguruan dan Ilmu Pendidikan, Universitas Victory Sorong ${ }^{1,2}$ \\ Email.vantrikelelufna70@gmail.com
}

\section{ARTICLE INFO}

Article History:

Accepted 11 September 2019

Available Online 27 Oktober 2019

Keywords:

Intelligence, Compound,

Enhancement, Achievement,

Learning.

\begin{abstract}
A person has compound intelligence is the foundation for improving cognitive, affective and psychomotor learning achievements. Individually, the multiple intelligences that a person has are more than one or heterogeneous, so that abilities may be developed with some compound intelligence. The method of study used is descriptive research that is intended to give a description of symptoms, events and actual circumstances, in this case would clearly depict a student has description of sound wave material using a compound wave method. Before student obtain treatment of sound wave material using a compound intelligence strategy, the student mastery level was still very low, but when given the treatment with the compound intelligence strategy the student mastery level experienced improvement.
\end{abstract}

\section{PEDAHULUAN}

Dalam era globalisasi saat ini, siswa mengalami sejumlah tantangan dalam cara memperoleh informasi. Kombinasi pendekatan pengajaran yang bermacam-macam perlu untuk mengubah pelajaran siswa dari belajar di permukaan ke belajar mendalam, pembelajaran pasif ke pembelajaran aktif, pembelajaran yang terlalu bergantung pada guru ke belajar mandiri dan membangun keterampilan generic saintis pada siswa serta keterampilan untuk belajar seumur hidup termasuk pemecahan masalah, keterampilan komunikasi dan bekerja sama. Selama ini pendidikan menilai kecerdasan manusia terlalu sempit, manusia 
dianggap hanya memiliki satu kecerdasan yang dapat diukur. Pembelajaran yang menekankan pada prestasi akademik akan menghasilkan siswa yang kurang inisiatif. Pendekatan yang mementingkan aspek akademik cenderung memberikan tekanan pada perkembangan kecerdasan.

Kecerdasan merupakan salah satu diantara kata-kata yang diyakini setiap orang bahwa mereka memahaminya. Kecerdasan dapat didefinisikan sebagai bakat umum untuk belajar atau kemampuan untuk mempelajari dan menggunakan pengetahuan dan keterampilan. Gagasan bahwa kinerja yang baik atau buruk dalam satu bidang sama sekali tidak menjamin kinerja serupa dalam bidang lain. Guru harus menghindari berpikir tentang siswa sebagai orang yang cerdas atau tidak cerdas, karena ada banyak cara untuk menjadi cerdas. Sayangnya, sekolah secara tradisional telah mengakui hanya seperangkat kinerja yang sempit, dengan menciptakan hierarki siswa yang teratur terutama berdasar apa yang disebut Gardner sebagai kemampuan verbalistik dan logis matematis. Apabila sekolah menginginkan semua siswa menjadi cerdas, mereka harus menggunakan rentang kegiatan yang lebih luas dan member imbalan bagi rentang kerjanya yang lebih luas daripada yang mereka lakukan pada masa lalu (Slavin R. E, 2009:161-162).

Howard Gardner memperkenalkan penelitiannya yang berkaitan dengan multiple intelligences (kecerdasan majemuk). Ada delapan kecerdasan yang diidentifikasi antara lain kecerdasan lingustik, kecerdasan logis matematis, kecerdasan spasial, kecerdasan musikal, kecerdasan kinestetik badani, kecerdasan interpersonal, dan kecerdasan intrapersonal. Namun dalam perkembangan ada beberapa kecerdasan juga yang telah ditemukan diantaranya kecerdasan naturalis, kecerdasan spiritual, dan kecerdasan eksistensial.

Sesuai hasil analisis data terdapat hubungan yang signifikan antara Multiple Intelligences dengan hasil belajar kognitif siswa pada mata pelajaran Ilmu Pengetahuan Alam di kelas VII Sekolah Menengah Pertama Negeri 1 Kayam Hulu. Hal ini dibuktikan dengan koefisien hubungan antara Multiple Intelligences dengan hasil belajar kognitif siswa pada mata mata pelajaran Ilmu Pengetahuan Alam sebesar 0.490 berdasarkan interpretasi nilai menunjukkan bahwa terdapat hubungan yang sedang (Ege B, Supiandi M.I, \& Ridho D. A. S, 2016:4). Ada juga hasil penelitian tentang kecerdasan yang menyatakan bahwa berdasarkan pengolahan data yang telah dilakukan, maka dapat ditarik kesimpulan bahwa siswa yang diajar dengan model pembelajaran PBL mempunyai hasil belajar matematika yang lebih baik daripada siswa yang diajar dengan menggunakan model pembelajaran konvensional (M. Saufi \& M. Royani, 2016:9). Pada proses pembelajaran IPA menggunakan model pembelajaran Somatic, Auditory, Visual, Intelectualy (SAVI) siswa dapat dengan mudah memahami dan menguasai materi yang dipelajari. Hasil belajar yang diperoleh dikatakan sangat memuaskan, hal ini dapat terlihat dari peningkatan secara terus menerus dari setiap tindakan penelitian (Budiyanti Y \& Khairunnisa, 2019:4). Oleh karena ada hubungan dan hasil dari Multiple Intelligences terhadap hasil pembelajaran yang dilakukan maka peneliti merasa perlu untuk mencari tahu tingkat penguasaan materi gelombang bunyi pada siswa SMA Negeri 3 Sorong dengan menggunakan beberapa kecerdasan sesuai hasil tes kecerdasan.

Teori kecerdasan majemuk ditemukan dan dikembangkan oleh Gardner, seorang psikolog perkembangan dan professor pendidikan dari Graduate School of Education, Harvard University America Serikat pada tahun 1983. Gardner mendefinisikan 
intelligences sebagai kemampuan untuk memecahkan persoalan dan menghasilkan produk dalam suatu setting yang bermacam-macam dan dalam situasi yang nyata. Intelligences bukanlah kemampuan seseorang untuk menjawab soal-soal tes IQ dalam ruang tertutup yang terlepas dari lingkungannya. Akan tetapi, intelligences memuat kemampuan seseorang untuk memecahkan persoalan yang nyata dan dalam situasi yang bermacam-macam. Seseorang memiliki intelligences yang tinggi apabila ia dapat menyelesaikan persoalan hidup yang nyata, bukan hanya dalam teori. Semakin seseorang terampil dan mampu menyelesaikan persoalan kehidupan yang situasinya bermacam-macam dan kompleks, semakin tinggi intelligencenya (Chatib M, 2010:89).

Kecerdasan merupakan salah satu faktor utama yang menentukan sukses gagalnya peserta didik dalam belajar. Peserta didik yang mempunyai taraf kecerdasan rendah atau di bawah normal sukar diharapkan bermotivasi tinggi. Tetapi tidak ada jaminan bahwa dengan taraf kecerdasan tinggi seseorang secara otomatis akan sukses belajar di sekolah. Berbagai ilmu dari Gardner yang telah menemukan teori kecerdasan majemuk atau multiple intelligence bahwa ada banyak kecerdasan yang dimiliki setiap orang. Teori ini juga menekankan pentingnya "model" atau teladan yang sudah berhasil mengembangkan salah satu kecerdasan hingga puncak (Djaali, 2007:73).

Teori kecerdasan majemuk merupakan validasi tertinggi gagasan bahwa perbedaan individu adalah penting. Pemakaiannya dalam pendidikan sangat tergantung pada pengenalan, pengakuan dan penghargaan terhadap setiap atau berbagai cara siswa belajar, di samping pengenalan, pengakuan dan penghargaan terhadap setiap minat masing-masing siswa. Teori kecerdasan majemuk bukan hanya mengakui perbedaan individual ini untuk tujuan-tujuan praktis, seperti pengajaran dan penilaian, tetapi juga menganggap serta menerimanya sebagai sesuatu yang normal, wajar, bahkan menarik dan sangat berharga (Jasmine J, 2007:13).

Gardner mengenalkan teori kecerdasan majemuk yang menyatakan bahwa kecerdasan meliputi delapan kecerdasan. Yaitu linguistik, matematis, visual, musikal, kinestetik, interpersonal, intrapersonal, dan naturalis. Teori tersebut didasarkan pada pemikiran bahwa kemampuan intelektual yang diukur melalui tes IQ sangatlah terbatas, karena tes IQ hanya menekan pada kemampuan logika (matematika) dan bahasa (Jasmine J, 2007). Padahal setiap orang mempunyai cara yang unik untuk menyelesaikan persoalan yang dihadapinya. Kecerdasan bukan hanya dilihat dari nilai yang diperoleh seseorang. Kecerdasan merupakan kemampuan yang dimiliki oleh seseorang untuk melihat suatu masalah, lalu menyelesaikan masalah tersebut atau membuat sesuatu yang dapat berguna bagi orang lain.

Teori kecerdasan majemuk Gardner sangat terkenal dikalangan pendidik karena menawarkan model untuk bertindak sesuai dengan yang kita yakini yaitu semua anak memiliki kelebihan. Menurut Howard Gardner melihat kecerdasan seseorang dalam sebuah nilai dan tes yang terstandard, ia mendefinisikan kecerdasan sebagai:

1. Kemapuan seseorang untuk menyelesaikan masalah dalam kehidupan nyata.

2. Kemampuan untuk menciptakan masalah baru untuk diselesaikan.

3. Kemampuan untuk menghasilkan sesuatu (produk) atau menawarkan sebuah pelayanan yang dihasilkan dari kebudayaannya. 
Jadi, menurut Gardner dalam bukunya yang berjudul Frames of Mind: Teori Multiple Intelegences tahun 1983 mendefinisikan kecerdasan sebagai kemampuan untuk memecahkan suatu masalah, menciptakan suatu (produk) yang bernilai dalam suatu budaya (Kompasiana, 29 April 2018).

Adapun macam-macam kecerdasan tersebut yaitu:

1. Kecerdasan linguistik adalah kemampuan untuk menyusun pikiran dengan jelas dan mampu mengungkapkannya melalui kata-kata seperti berbicara, membaca atau menulis.

2. Kecerdasan matematis-logis adalah kemampuan untuk menangani bilangan dan perhitungan, serta pola pemikiran logis dan ilmiah.

3. Kecerdasan visual adalah kemampuan melihat suatu objek dengan detail.

4. Kecerdasan musikal adalah kemampuan untuk mengembangkan, mengekspresikan musik, irama, nada dan suara.

5. Kecerdasan kinestetik adalah kemampuan menggabungkan gerakan fisik dan pikiran sehingga menghasilkan gerakan yang sempurna.

6. Kecerdasan interpersonal adalah kemampuan untuk mengerti dan memahami orang lain.

7. Kecerdasan intrapersonal adalah kemampuan yang berkaitan dengan pengetahuan akan diri sendiri dan bertanggung jawab atas kehidupannya sendiri.

8. Kecerdasan naturalis adalah kemampuan untuk mengerti alam lingkungan dengan baik, kemampuan untuk memahami dan menikmati alam, dan mengenali berbagai jenis flora fauna dan fenomena alam lainnya.

9. Kecerdasan spiritual adalah kemampuan untuk merasakan keberagaman atau macam-macam seseorang.

Kesembilan kecerdasan tersebut perlu dikembangkan secara maksimal sejak usia dini agar bermanfaat bagi setiap anak tersebut (Hadijah, S. 3 Juni 2017). Adapun kecerdasan majemuk terbentuk karena faktor:

1. Hereditas yaitu faktor bawaan dari keturunan.

2. Lingkungan merupakan faktor yang berpengaruh besar untuk menghasilkan kemampuan fungsionalitas organ kecerdasan pada anak.

3. Nutrisi, asupan nutrisi merupakan salah satu faktor yang mendukung kecerdasan anak.

Penting bagi pendidik dan orang tua untuk mengetahui kecerdasan setiap anak. Karena jika salah dalam pemberian stimulus, maka kecerdasan tersebut bisa hilang atau terkubur oleh stimulus-stimulus yang lain dan bisa membuat anak terus-terusan beradaptasi dengan hal-hal baru yang bukan dalam bidang mereka. Dengan stimulus yang tepat dalam setiap kecerdasan, maka setiap anak akan mudah untuk melakukan dan mengeksplorasikan kecerdasan maupun bakat yang sudah mereka miliki. Dalam proses pembelajaran guru menginginkan siswanya berhasil secara kognitif, afektif, dan psikomotor. Oleh karena itu metode pembelajaran harus disesuaikan dengan kecerdasan yang 
lebih unggul pada masing-masing siswa, karena siswa memiliki kecerdasan yang heterogen dan merasa lebih menyenangkan ketika materi pelajaran diajarkan sesuai dengan kecerdasan yang dimiliki. Dengan demikian teori Howard Gardner tentang kecerdasan majemuk akan lebih bermanfaat jika diterapkan dalam pembelajaran fisika sehingga adanya kesan baik yang dirasakan oleh siswa dalam proses belajar mengajar dan diharapkan akan terjadi peningkatan prestasi belajar siswa.

Berdasarkan uraian diatas maka yang menjadi rumusan masalah adalah apakah penerapan strategi kecerdasan majemuk dapat membantu siswa dalam mencapai hasil belajar Fisika materi Gelobang Bunyi pada siswa SMA Negeri 3 Sorong. Adapaun beberapa indikator yang mesti dicapai dalam proses penelitian yaitu kemampuan kecerdasan majemuk untuk setiap siswa, kemampuan pre test, kemampuan proses selama kegiatan penelitian berlangsung, kemampuan post test, dan nilai akhir. Tujuan yang ingin dicapai dari penelitian merupakan serangkaian kegiatan yang dilakukan dengan memperhatikan kecerdasan majemuk yang dimiliki oleh setiap siswa, tingkat pencapaian pada hasil pre test yang dilakukan terhadap siswa, nilai proses yang diperoleh dari setiap siswa selama kegiatan penelitian dilakukan, tingkat pencapaian pada hasil post test yang dilakukan terhadap siswa, dan nilai akhir dari semua rangkaian kegiatan.

\section{METODE PENELITIAN}

Tipe penelitian yang digunakan adalah penelitian deskriptif yang bertujuan untuk memberikan gambaran tentang suatu gejala, peristiwa, dan keadaan sebenarnya dalam hal ini akan menggambarkan secara jelas mengenai penguasaan siswa terhadap materi gelombang bunyi dengan menerapkan kecerdasan majemuk (multiple intelegences) yang melibatkan 31 orang siswa kelas XII IPA SMA Negeri 3 Sorong sebagai sampel.

Adapun instrument yang digunakan untuk memperoleh data dalam penelitian adalah tes yang meliputi tes awal dan tes formatif serta non tes berupa angket kecerdasan majemuk (multiple intelligences). Menurut (Arikunto 1999:27) penilaian proses dalam hal ini melalui penilaian kognitif, afektif, dan psikomotor menggunakan rumus:

$$
\text { Skor }=\frac{s p h a}{s \quad m} \times 100
$$

Setiap guru mempunyai pendapat sendiri tentang cara menentukan nilai akhir yang diperoleh menurut pandangan sendiri tentang penting dan tidaknya kegiatan yang dilakukan siswa. Maka nilai akhir yang menggambarkan tingkat penguasaan individu terhadap indikator kompetensi materi gelombang bunyi dengan menggunakan rumus:

$$
N=\frac{6 P+4 F}{10}
$$

Selanjutnya nilai akhir yang menggunakan tingkat pencapaian minimum individual. 
Tabel 1 Kualifikasi Niali Akhir

\begin{tabular}{|c|c|}
\hline Tingkat Pencapaian & Kualifikasi \\
\hline $85-100$ & Sangat Baik \\
\hline $71-84$ & Baik \\
\hline $58-70$ & Cukup \\
\hline$<58$ & Gagal \\
\hline
\end{tabular}

\section{HASIL PENELITIAN DAN PEMBAHASAN}

\section{HASIL PENELITIAN}

\section{Frekuensi Kecerdasan Mahasiswa}

Sebelum proses belajar mengajar diterapkan siswa diminta untuk mengisi angket tes kecerdasan untuk mengetahui tingkat kecerdasan yang dimiliki oleh siswa dan berdasarkan hasil tes kecerdasan, siswa dibagi dalam kelompok kecerdasan yang heterogen.

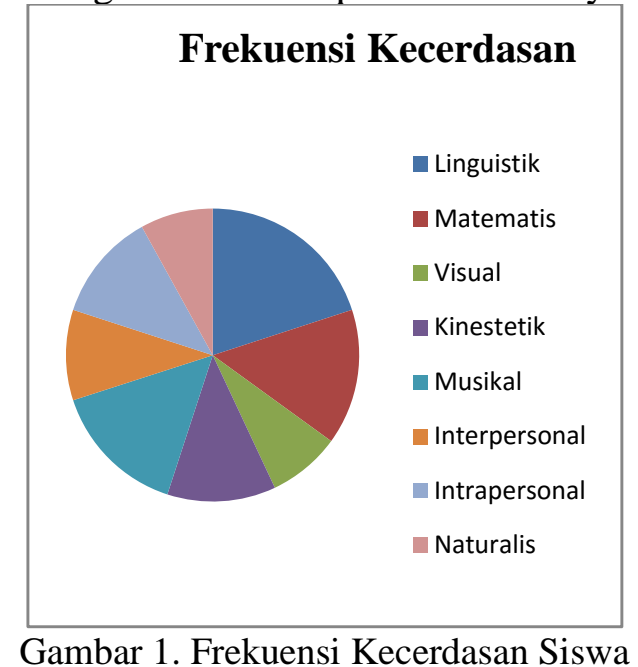

Gambar 1 menunjukan bahwa kecerdasan majemuk yang dimiliki siswa beragam dan dapat dilihat pada diagram dimana skor yang diperoleh untuk masing-masing kecerdasan sebagai berikut linguistik $20 \%$, matematis $15 \%$, visual $8 \%$, kinestetik $12 \%$, musical $15 \%$, interpersonal $10 \%$, intrapersonal $12 \%$, naturalis $8 \%$. Berdasarkan hasil frekuensi kecerdasan maka ada empat kecerdasan yang digunakan untuk proses penelitian yaitu kecerdasan linguistik, kecerdasan matematis, kecerdasan kinestetik, dan kecerdasan musikal.

\section{Kemampuan Awal Siswa}

Kemampuan awal siswa sebelum perlakuan menunjukan bahwa hasil pre test berada pada kualifikasi dibawah kriteria ketuntasan mengajar karena siswa belum mampu menguasai indikator pembelajaran. Berdasarkan data hasil pre test kemampuan siswa secara keseluruhan dinyatakan gagal dan dapat dilihat pada tabel kemampuan awal siswa. 
Tabel 2 Kemampuan Tes Awal

\begin{tabular}{|c|c|c|c|}
\hline Pencapaian & Frekuensi & Persentase & Kualifikasi \\
\hline $85-100$ & 0 & 0 & Sangat baik \\
\hline $71-84$ & 0 & 0 & Baik \\
\hline $58-70$ & 0 & 0 & Cukup \\
\hline$<50$ & 31 & 100 & Gagal \\
\hline Jumlah & $\mathbf{3 1}$ & $\mathbf{1 0 0}$ & \\
\hline
\end{tabular}

\section{Penilaian Proses}

Data hasil penelitian penilaian proses menunjukan bahwa diperoleh 2 siswa (7\%) mencapai kualifikasi sangat baik, 29 siswa (93\%) mencapai kualifikasi baik, dan tidak ada siswa yang mencapai kualifikasi cukup maupun gagal. Berdasarkan data hasil penelitian maka rata-rata persentase $82 \%$ dengan kualifikasi baik.

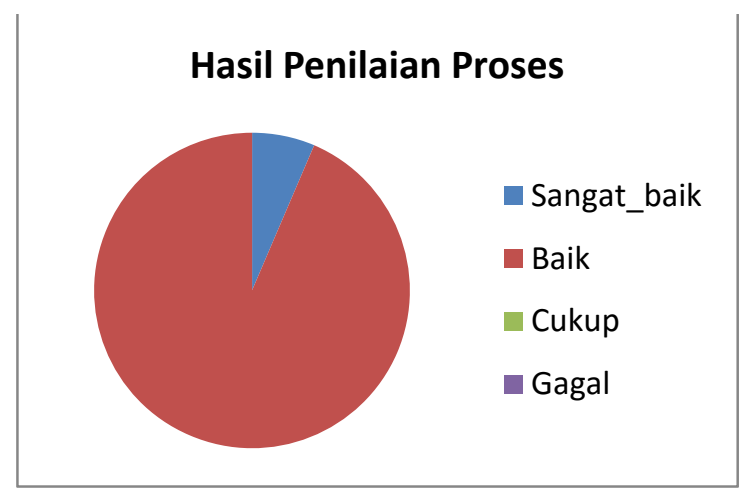

Gambar 2 Hasil Penilaian Proses

\section{Penilaian Post Test}

Setelah dilakukan pre test dan penilaian proses dalam proses penelitian maka selanjutnya dilakukan post test atau tes formatif kepada siswa secara individual dimana nilai masingmasing siswa dapat dikelompokan berdasarkan tingkat pencapaian pada diagram berikut. 


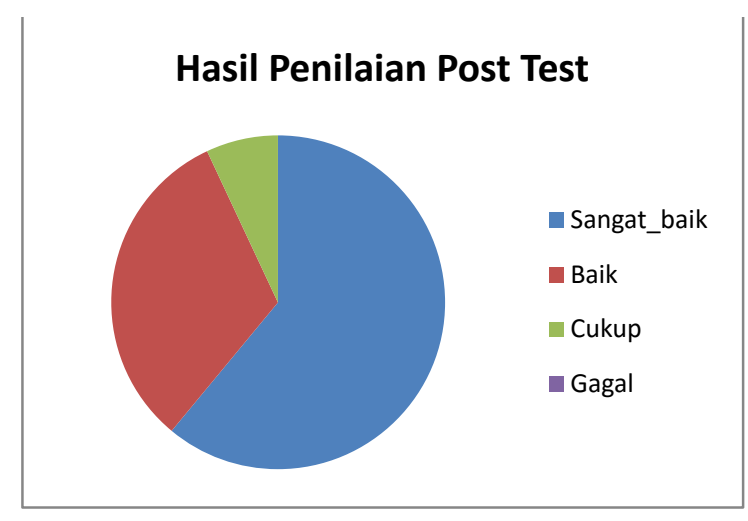

Gambar 3 Hasil Penilaian Post Test

Gambar 3 menunjukan bahwa 19 siswa (61\%) yang mencapai kualifikasi sangat baik, 10 siswa (32\%) mencapai kualifikasi baik, 2 siswa mencapai kualifikasi cukup, dan tidak ada siswa yang mencapai kualifikasi gagal. Berdasarkan data post test maka rata-rata tingkat pencapaian $85 \%$ dan dapat dapat dikategorikan sangat baik.

\section{Kemampuan Nilai Akhir}

Ketika telah memperoleh nilai proses dan nilai post test maka dapat dilakukan perhitungan untuk mencapai nilai akhir dan berikut adalah tabel kualifikasi pencapaian nilai akhir.

Tabel 3. Kemampuan Niali Akhir

\begin{tabular}{|c|c|c|c|}
\hline Pencapaian & Frekuensi & Persentase & Kualifikasi \\
\hline $85-100$ & 12 & 39 & Sangat baik \\
\hline $71-84$ & 19 & 61 & Baik \\
\hline $58-70$ & 0 & 0 & Cukup \\
\hline$<50$ & 0 & 0 & Gagal \\
\hline Jumlah & 31 & 100 & \\
\hline
\end{tabular}

Tabel 3 menunjukan kualifikasi nilai akhir yang menggambarkan bahwa siswa mampu memperoleh nilai akhir dengan kualifikasi sangat baik sebanyak 12 siswa (39\%), 19 siswa (61\%) memperoleh kualifikasi baik, dan tidak ada siswa yang memperoleh kualifikasi cukup maupun gagal.

\section{PEMBAHASAN}

Penelitian diawali dengan tes kecerdasan terhadap 31 siswa dengan tujuan untuk mengetahui kecerdasan yang dimiliki oleh siswa secara individu dan dari hasil tes siswa 
dibagi dalam kelompok kecerdasan yang heterogen. Siswa memiliki hampir semua kecerdasan dengan skor perolehan yang berbeda-beda dan ada yang mencapai skor yang sangat menonjol. Setelah melakukan tes kecerdasan dilanjutkan dengan Pre Test terhadap siswa untuk mengetahui kemampuan awal siswa sebelum dilakukan perlakuan. Hasil Pre Test menggambarkan kemampuan siswa terhadap materi yang diajarkan belum mencapai skor kriteria ketuntasan mengajar dengan demikian bisa dikatakan semua siswa gagal karena belum menguasai indikator yang akan dicapai.

Peneliti memberikan perlakuan kepada siswa dengan melakukan kegiatan belajar mengajar dengan menerapkan strategi kecerdasan majemuk pada materi gelombang bunyi. Setelah itu siswa dibagikan dalam kelompok kecerdasan yang heterogen kemudian peneliti membagikan lembar kerja siswa (LKS) kepada kelompok untuk dikerjakan sesuai petunjuk berdasarkan kecerdasan majemuk dan semua jawaban dari setiap kelompok akan dinilai pada saat presentase.

Proses kegiatan belajar mengajar berlangsung ada 3 aspek yang diukur yakni aspek kognitif, aspek afektif, dan aspek psikomotor. Dalam proses kegiatan belajar mengajar siswa mampu menunjukan kompetensi yang dimiliki dan menggambarkan proses membangun pemahaman siswa pada materi gelombang bunyi menggunakan strategi kecerdasan majemuk sangat membantu siswa. Ketuntasan belajar secara individual maupun kelompok pada aspek kognitif berada pada kualifikasi sangat baik dan baik yang ditunjukkan pada nilai lembar kerja siswa (LKS). Pencapaian aspek afektif dan psikomor terlihat pada presentase, partisipasi, kerja sama, menghargai pendapat teman, mendengar dan menerima informasi. Secara klasikal maupun individual semua siswa tuntas walaupun dengan kualifikasi yang berbeda-beda.

Setelah kegiatan belajar mengajar maka peneliti melakukan Post Test untuk mengetahui kemampuan siswa. Hasil yang diperoleh menggambarkan kualifikasi hasil pencapaian siswa pada penilaian Post Test yang mana 31 siswa telah tuntas belajar dengan kualifikasi yang berbeda. Kegiatan belajar mengajar menggunakan strategi kecerdasan majemuk pada materi gelombang bunyi membuat siswa senang dan aktif dalam kegiatan belajar serta bekerjasama dalam kelompok dan mampu memecahkan masalah. Hal ini terjadi karena siswa dapat belajar memahami materi pelajaran dengan kecerdasan yang lebih menonjol pada dirinya sehingga dengan mudah dan tanpa harus memaksakan diri untuk memahami materi dengan kecerdasan orang lain yang pada akhirnya akan berpengaruh pada pencapaian hasil belajar yang tidak maksimal. Nilai akhir siswa dalam kegiatan belajar mengajar menunjukan bahwa semua siswa boleh mencapai kriteria ketuntasan mengajar yang diperoleh dari penilaian proses dan Post Test sehingga siswa memperoleh nilai akhir yang memuaskan yakni 31 siswa telah tuntas belajar karena telah memahami dan menjawab indikator dalam proses pembelajaran. Menurut dosen pendidikan (2019) hasil belajar merupakan kemampuan-kemampuan yang dimiliki siswa setelah menerima pengalaman belajarnya. Kemampuankemampuan tersebut mencakup aspek kognitif, afektif dan psikomotorik. Hasil belajar dapat dilihat melalui kegiatan evaluasi yang bertujuan untuk mendapatkan data pembuktian yang akan menunjukkan tingkat kemampuan siswa dalam mencapai tujuan pembelajaran. Berdasarkan hasil yang diperoleh maka dapat dikatakan bahwa hasil belajar yang dicapai dengan menggunakan strategi kecerdasan majemuk dalam kegiatan belajar mengajar pada materi gelombang bunyi dapat membantu siswa untuk belajar dengan kecerdasannya sehingga menyenangkan dan mudah memahami indikator yang akan dicapai. 


\section{KESIMPULAN}

Sesuai hasil penelitian yang dilakukan maka peneliti dapat mengambil kesimpulan bahwa sebelum siswa memperoleh perlakuan terhadap materi gelombang bunyi dengan menggunakan strategi Multiple Intelligences tingkat penguasaan siswa masih sangat rendah, namun ketika diberikan perlakuan dengan strategi Multiple Intelligences maka tingkat penguasaan siswa mengalami peningkatan.. Oleh karena itu penulis menyarankan kepada para guru agar lebih memperhatikan Multiple Intelligences dari siswa dalam proses pembelajaran sehingga kecerdasan yang dimilki oleh siswa lebih ditingkatkan dalam rang peningkatan prestasi belajar siswa.

\section{DAFTAR PUSTAKA}

Arikunto, S., 1991 Prosedur Penelitian. Jakarta: Rineka Cipta

Budiyanti, Y \& Khairunnisa., 2019. Upaya Meningkatkan Pemahaman Konsep Melalui Model Pembelajaran Somatic, Auditory, Visualization, Intelectualy (Savi) Pada Mata Pelajaran Ipa Siswa Kelas V Mi Mifftahul Huda Kota Bekasi. PEDAGOGIK Vol. VII, No. 2, September 2019

Chatib, M., 2010. Sekolahnya Manusia, Sekolah Berbasis Multiple Intelligence di Indonesia. Bandung: Kaifa

Depdiknas., 2008. Kamus Besar Bahasa Indonesia Edisi Keempat. Jakarta: Gramedia Pustaka Utama.

Dimyati \& Mudjiono., 2009. Belajar dan Pembelajaran. Jakarta: Rineka Cipta.

Djaali., 2007. Psikologi Pendidikan. Jakarta: Bumi Aksara

Ege, B., Supiandi, M. I., \& Ridho, D. A. S., 2016. Hubungan Antara Multiple Intelligences Dengan Hasil Belajar Kognitif Siswa Pada Mata Pelajaran Ilmu Pengetahuan Alam. Vol. 1, 2016, ISBN: 978-602-9286-21-2

Hadijah, S. 2017. Tipe Kecerdasan yang Dimiliki Manusia. Info Umum

Jasmine, J., 2007. Panduan Praktis Mengajar Berbasis Kecerdasan Majemuk. Bandung: Nuansa

Kompasiana. 29 April 2018. Mengenal Kecerdasan Majemuk (Multiple Intelligence) kepada Anak

Saufi, M., \& Royani, M., 2016. Mengembangkan Kecerdasan Interpersonal dan Kepercayaan Diri Siswa Melalui Efektivitas Model Pembelajaran PBL. Vol. 2, No. 2, Mei - Agustus 2016

Suryabrata, S., 2006. Psikologi Pendidikan. Jakarta: Raja Grafindo Persada. 